\title{
Injuries among Portuguese kitesurfers: The most affected body regions. A pilot study
}

\section{Lesões mais frequentes em praticantes Portugueses de Kitesurf. Um Estudo Piloto}

\author{
Bruno Silva ${ }^{1,2 *}$, Ricardo Viana ${ }^{1,2}$, Ana Gama ${ }^{1,2}$, José António Pérez-Turpin ${ }^{3}$, Pedro Bezerra ${ }^{1,2}$ \\ ORIGINAL ARTICLE | ARTIGO ORIGINAL
}

\begin{abstract}
Aquatic sports keep rising in popularity. Kitesurfing is a high-risk sport that combines aspects of several water sports. Kitesurfing is a relatively new water sport, and the understanding of the injuries due to its practice has not yet been largely investigated. The purpose of this study is to investigate the most common types and causes of injuries among Portuguese kitesurfers. The data was collected using a retrospective 12 months web-based questionnaire. A total of 87 kitesurfers, mostly from the North, showed that $75.9 \%$ have a kitesurfing initiation course and $56.3 \%$ use protective equipment. A total of $60.9 \%$ has been injured in the 12 month's period, being the knee and the lumbar spine the most common body injury. A reasonable number of injuries occurred while performing a landing or a maneuver, being $53.9 \%$ of the injuries reported as a new injury. This 12 month's retrospective study supports earlier studies and provides basis knowledge about the incidence of Portuguese kitesurfers injuries. The data support the benefits of physical fitness $(\mathrm{p}<$ $0.05)$ in injuries prevention.
\end{abstract}

Keywords: Kitesurf, injury, physical fitness, prevention

RESUMO A popularidade dos desportos aquáticos tem vindo a aumentar. O kitesurf é um atividade desportiva que combina vários desportos aquáticos, podendo ser considerada uma atividade de alto risco. Os perigos inerentes a estes desportos têm sido amplamente estudados. No entanto, o kitesurf apresenta-se como um desporto relativamente recente e em evolução, onde o entendimento sobre as principais lesões resultantes da sua prática ainda não estão amplamente investigadas. Deste modo, o objetivo deste estudo é identificar as lesões mais frequentes nos kitesurfers Portugueses, bem como as partes do corpo mais afetadas e os elementos causadores dessas lesões. Os dados foram recolhidos segundo um questionário retrospetivo a 12 meses, com base na Internet. A amostra é composta por 87 kitesurfers, residentes maioritariamente no Norte de Portugal. A sua maioria $(75,9 \%)$ têm curso de iniciação ao kitesurf e utilizam algum tipo de equipamento de proteção $(56,3 \%)$. Destes $60.9 \%$ reportaram a ocorrência de uma lesão ao longo dos últimos 12 meses, onde o joelho e a zona lombar foram os locais mais afetadas. A generalidade das lesões reportadas $(53.9 \%)$ são novas lesões, que ocorreram maioritariamente em sequência de uma manobra ou após um salto. Os dados recolhidos reforçam outros estudos já realizados, proporcionando dados mais concretos sobre os kitesurfers Portugueses. Por outro lado sustentam ainda os benefícios da condição física dos praticantes $(\mathrm{p}<0.05)$ na prevenção de lesões.

Palavras-chave: Kitesurf; lesões; condição física; prevenção

\footnotetext{
Manuscript received at October 23 ${ }^{\text {rd }} 2014$; Accepted at November $13^{\text {th }} 2015$

${ }^{1}$ School of Sports and Leisure, Viana do Castelo Polytechnic Institute (Portugal);

${ }^{2}$ Research Center in Sports Science, Health and Human Development (CIDESD), Portugal

${ }^{3}$ Departmental Section of Physical Education and Sports, University of Alicante (Spain);

* Corresponding author: Bruno Silva; Complexo Desportivo e Lazer de Melgaço - Monte Prado 4960-320 Melgaço - Portugal E-mail: silvabruno@esdl.ipvc.pt
} 


\section{INTRODUCTION}

The past two decades have seen the development and increased popularity of new sports such as kitesurfing (Kupciw \& MacGregor, 2012), which is a high-risk sport that is growing in attractiveness and which combines aspects of several water sports (Bourgois, Boone, Callewaert, Tipton, \& Tallir, 2014; Kupciw \& MacGregor, 2012; Vercruyssen, Blin, L'Huillier, \& Brisswalter, 2009). The danger associated with high-risk sports has become socially accepted in Western Society (Kupciw \& MacGregor, 2012), however, the risk of injury is always present.

An injury is defined as any physical or psychological complaint resulted in incapacity to practice or compete normally (Clarsen \& Bahr, 2014; Nickel et al., 2004). The quickrelease safety system, that enables the participant to detach the equipment, and the $100 \%$ depowerable kites where introduced in 2004 - 2005, as an important strategy to prevent accidents (Ziegler, Lockemann, \& Püschel, 2009).

In the literature, when considering injuries related to kitesurfing, it can only be found 3 reviews between 2005 and 2014 and about another 15 original articles (Bourgois et al., 2014). In Portuguese we can find 3 publications, 1 review article (Machado \& Coertjens, 2011) and 2 original articles (Berneira, Domingues, Medeiros, \& Vaghetti, 2011; Cruz, Brito, \& Cruz, 2009), regarding Brazilian kitesurfers.

To the best of our knowledge there is no article that characterizes the incidence of injuries among Portuguese kitesurfers.

This study aims to investigate the incidence of injuries in Portuguese kitesurfers, to better understand the associated injury mechanisms, as well as to provide physicians, coaches and athletes with a clear understanding of this specific population group.

\section{METHODS}

\section{Participants}

The subjects who participated in the study had at least, one year of Kitesurfing experience, either competitive or recreational. A total of 87 kitesurfers, all residents in Portugal, had completed the questionnaire. From the 87 respondents, 5 were female and 82 were male. Their ages ranged from 15 to 60 years with an average of $34.2 \pm 9.1$ and a practice period from 1 to 14 years, with a mean of $4.9 \pm 3.2$. The participants were distributed according to the Portuguese Nomenclature of Territorial Units for Statistics (North, Center, Lisbon and Tejo Valley, and South), representing the North $64.4 \%$ of the total participants (Table 1 ).

\section{Instruments}

The data was collected using a web-based questionnaire in Portuguese, distributed in an open web, through an application on Google drive, in order to reach kitesurfers from all the Portuguese regions. This 12-month retrospective questionnaire, was adapted to Portuguese, from the previously version of (Pérez-Turpin et al., 2012) and applied to a board of experts including kitesurfers (recreational and competitive athletes) and kitesurf instructors that reviewed the questionnaire.

\section{Procedures}

Subjects from continental regions of Portugal completed the web-based questionnaire. It was available for one month (from 11 October to 11 November 2013), via https://docs.google.com/forms/d/1IFIgCJ9S1IIiKiOrip81spTCrb-

F7pw86FEUzwC7q0/closedform. This site was linked to Facebook web pages of kitesurfing fans, kitesurfing forums, such as http://kiteboardlusitano.com and kite surfing schools. The answers were confidential and the subjects would not be able to be identified. The questionnaire took about eight minutes to complete and contained questions about; (i) general information, (ii) physical activity, (iii) protection systems used and the most frequent style (Freestyle, Waves, Race our Freeride) (iv) injuries, chosen from a list of musculoskeletal injuries, body regions and pain, and (v) general information about the consequences of the injuries in daily life (for details see PérezTurpin et al., 2012). 


\section{Statistical Analysis}

Data was downloaded and checked for completeness and plausibility before being analyzed by using the SPSS version 22.0 for Windows. Descriptive statistics were used for analysis and presentation of the results by checking mean values, standard deviation, coefficient of variance, and percentage. Due to the sample distribution it was necessary a nonparametric tests and a Mann-Whitney test was applied, for two independent groups, and the Kruskal-Wallis test for three or more independent groups with the post hoc Dunnett's T3 to confirm where the differences occurred, according to is applicable assumptions. The significance level was set at $\mathrm{p}$ $<0.05$.

Table 1

Sample Characterization

\begin{tabular}{|c|c|c|}
\hline \multirow{4}{*}{ Age } & $\leq 25$ & $15(17.2)$ \\
\hline & $26-35$ & $39(44.8)$ \\
\hline & $36-45$ & $21(24.1)$ \\
\hline & +46 & $12(13.8)$ \\
\hline \multirow[t]{2}{*}{ Gender } & Female & $82(94.3)$ \\
\hline & Male & $5(5.7)$ \\
\hline \multirow{3}{*}{ Time in sport } & $1-3$ years & $39(44.8)$ \\
\hline & 4- 6 years & $21(24.1)$ \\
\hline & More than 7 & $27(31.0)$ \\
\hline \multirow{5}{*}{ Region } & North & $56(64.4)$ \\
\hline & Center & $12(13.8)$ \\
\hline & Lisbon and Tejo Valley & $16(18.4)$ \\
\hline & South & $2(2.3)$ \\
\hline & missing & $1(1.1)$ \\
\hline \multirow{2}{*}{ Initiation kitesurfing course } & Yes & $66(75.9)$ \\
\hline & No & $21(24.1)$ \\
\hline \multirow{2}{*}{\multicolumn{2}{|c|}{ Physical Fitness to improve kitesurfing }} & $33(37.9)$ \\
\hline & & $54(62.1)$ \\
\hline \multirow{3}{*}{ Warm up before kitesurfing } & Non & $26(29.9)$ \\
\hline & Some times & $48(55.2)$ \\
\hline & Always & $13(14.9)$ \\
\hline \multirow{3}{*}{ Safety equipment } & Non & $38(43.7)$ \\
\hline & Some times & $17(19.5)$ \\
\hline & Always & $32(36.8)$ \\
\hline \multirow{11}{*}{ Type Practice } & Freeride & $34(39.1)$ \\
\hline & Freeride and Waves & $11(12.6)$ \\
\hline & Freeride and Freestyle & $7(8.0)$ \\
\hline & Freeride, Freestyle and Waves & $7(8.0)$ \\
\hline & Freestyle & $6(6.9)$ \\
\hline & Waves & $5(5.7)$ \\
\hline & Freeride and Waves & $4(4.6)$ \\
\hline & Race and Freeride & $4(4.6)$ \\
\hline & Waves, Race and Freeride & $2(2.3)$ \\
\hline & Race & $1(1.1)$ \\
\hline & Race and Freestyle & $1(1.1)$ \\
\hline
\end{tabular}

A total of 87 kitesurfers, mostly from the North of Portugal, males in the majority $(n=$ 82 ), with an average of $4.9 \pm 9.1$ years of practice, completed this survey. From the responders, $75.9 \%$ have a kitesurfing initiation course and $56.3 \%$ assumed the use of protective equipment. However, the responders using protective equipment, $65.3 \%$, have reported the use of it in all situations, being the use of the impact vest their top preference. In the injured group, $49.1 \%$ of the subjects used at least one or more protective gears.

The most common board used is the TWINTIP model (77.0\%) and half of the responders practice more often the freeride style in detriment of the other kiteboarding styles (table 1). 
Most of the subjects (62\%) reported that they do not have any physical fitness program in order to improve the kitesurfing practice and $70.1 \%$ assume to warm up before the practice, but only $14.9 \%$ have been completing it every time they practice.

In this study 53 subjects reported an injury and 35 had multiple injuries during the last 12 months, 14 surfers reported 2 injuries, 9 surfers reported 3 injuries and 12 surfers reported 4 injuries or more.

The most common injury types were a Superficial Wound $(n=18)$, Sprain $(n=18)$ and Tendinitis $(n=14)$ (Table 2).

Table 2

Types and frequency of injuries reported, in kitesurfers

\begin{tabular}{lc}
\hline Injury & $\mathrm{n}(\%)$ \\
\hline Superficial Wound & $18(18.5)$ \\
Sprain & $18(18.5)$ \\
Tendinitis & $14(14.4)$ \\
Contusion & $13(13.4)$ \\
Joint Dislocation & $11(11.3)$ \\
Burn & $7(7.2)$ \\
Irritation & $6(6.2)$ \\
Bone Fracture & $5(5.2)$ \\
Muscle Stain & $3(3.1)$ \\
Other & $8(8.2)$ \\
\hline
\end{tabular}

The most affected parts of the body were the knee $(n=21)$, followed by the lumbar spine $(n=19)$, foot $(n=18)$ and toes $(n=18)$ (Table 3 ). The most common place of injury was the lower extremity (table 3 ), with the knee injury totaling $12.4 \%$. Twenty-four of the subjects $(27.6 \%)$ admitted that they had chronic pain during kitesurfing, being the knee $(n=9)$ and the lower back $(n=5)$ the most common body region, being a chronic injury the possible reason.

The majority of injuries occurred while performing a landing $(n=26)$ or a maneuver $(n=22)$, due to physical fitness $(n=20)$, fatigue $(n=20)$ or due to a jump $(n=19)$. A few amount of respondents reported having an injury incident because of the weather $(n=17)$, a gear problem $(n=7)$ or due to 'other' causes $(n=2)$. These data indicated that the majority of the injuries occurred in the water.
Table 3

Injurie Location and frequency reported, in kitesurfers

\begin{tabular}{lc}
\hline Injury & $\mathrm{n}(\%)$ \\
\hline Knee & $21(12.4)$ \\
Lumbar & $19(11.2)$ \\
Foot & $18(10.6)$ \\
Toes & $18(10.6)$ \\
Leg & $14(8.2)$ \\
Shoulder & $14(8.2)$ \\
Ankle & $12(7.1)$ \\
Wrist & $10(5.9)$ \\
Ears & $7(4.1)$ \\
Head & $5(2.9)$ \\
Elbow & $5(2.9)$ \\
Finger & $4(2.4)$ \\
Clavicle & $2(1.2)$ \\
Hand & $4(2.4)$ \\
Thigh & $4(2.4)$ \\
Chest & $3(1.8)$ \\
Hip & $3(1.8)$ \\
Forearm & $2(1.2)$ \\
Arm & $1(0.6)$ \\
Other & $4(2.4)$ \\
\hline Lower body & $90(52.9)$ \\
Upper body & $64(37.6)$ \\
Head & $12(7.1)$ \\
Other & $4(2.4)$ \\
\hline & \\
\hline
\end{tabular}

Overall, $53.9 \%$ of the injuries were reported as a new injury, but $35.9 \%$ indicate that it is a recurrent injury and $10.3 \%$ an increased injury. The greater part of the injuries occurred in summer (70.7\%).

In relation to injuries, having kitesurf initiation course $(p=0.738)$; perform warm-up $(\mathrm{p}=0.10)$; use protective equipment $(\mathrm{p}=$ $0.134)$; and having more experience (in years) $(p=0.269)$, seems not to be a differentiation factor. Furthermore, kitesurfers that enroll a physical fitness program have less injuries ( $p=$ 0.020).

When the injury group was asked to indicate the types of medical treatment received $43.4 \%$ reported they had consulted a physician (National Health System or private physician), $11.3 \%$ needed to see a rehabilitation specialist (e.g. physiotherapist or rehabilitation professional from a private insurance), while $13.2 \%$ used other treatment as a first aid kit or bed rest. Overall, $32.1 \%$ of the respondents did not require any medical treatment, independent of age. 


\section{DISCUSSION}

The purpose of this study was to investigate the incidence of injuries in Portuguese kitesurfers, to achieve a better understanding of associated injury mechanisms and explore potential interferences approaches.

The average age and years of practice is similar to other studies (Berneira et al., 2011; Cruz et al., 2009; Lundgren, Brorsson, \& Osvalder, 2011), explained by the fact of being a recent sport and that only $75,9 \%$ have a kite surfing initiation course. The number of women is low, but perhaps expressive of the female kitesurfers, because this percentage, $5.7 \%$, is found in other studies (Pikora, Braham, Hill, \& Mills, 2011).

When tested the influence of having kitesurf initiation course in the injuries rate, it was verified that it is not statistical significant $(\mathrm{p}=$ 0.738). Having an initiation course, it is an important safety approach when initiating kitesurfing, but in this sample it was not relevant in terms of being injured.

The percentage of kitesurfers that use protective equipment $(56.3 \%)$, is higher than in another studies (Lundgren et al., 2011). However, $19.5 \%$ of the participants of this group, does not use protective equipment in all situations. The fact that those who use protective equipment don't have less injuries $(p=0.134)$ it could be related to the circumstance that participants perception of risk and associated norms and practices are a core role in relation to decision to engage with risk and risk-management strategies (Powell, 2007). In the group of those that perform warm up, this same reason may mediating the fact that around $70.1 \%$ assume only perform the warm up sometimes. Other motive may be the fact that the impact vest is in the top of preferences, similar to the findings of (Lundgren et al., 2011) and the lower limb is where the most common injuries occur (Berneira et al., 2011; Lundgren et al., 2011; Nickel et al., 2004). Additionally, only $14.9 \%$ assumed to warm up always before practice, being the prevalence of injury not significantly lower among those who claimed to warm up $(p=0.10)$. This findings contrast with
(Lundgren et al., 2011) where the prevalence of injury was significantly lower among those who claimed to warm up.

A good level of general Physical Fitness is a useful predictor of kitesurfing performance (Bourgois et al., 2014). More than half of the subjects, $62.1 \%$, report that don't perform a physical activity in order to improve the kitesurfing practice, but those who enroll a physical fitness program have less injuries $(\mathrm{p}=$ 0.020). Moreover, 20 injuries were reported to be associated with Physical Fitness and another 20 due to fatigue. These two possible reported causes of injuries support this finding, because low physical fitness can lead to earlier fatigue, and together they affect performance (Ament \& Verkerke, 2009; Noakes, 2000), increasing the risks of injury.

Several studies (Berneira et al., 2011; Cruz et al., 2009; Lundgren et al., 2011; Nickel et al., 2004; Pérez-Turpin et al., 2011) indicated the contusion, abrasion and laceration are the most common injuries types. In the present study, the sprain is one of the most frequent (18.5\%), as demonstrated by (Berneira et al., 2011). In the other hand, Superficial Wound (18.5\%), and Tendinitis (14.4\%) represented the second and the third most common injury types (table 2).

The most affected body region was the knee with $12.4 \%$ injuries as stated in (Cruz et al., 2009; Lundgren et al., 2011). When analyzed the foot, toes and ankle together $(28.3 \%)$, the results were similar to (Nickel et al., 2004; Pérez-Turpin et al., 2011; Petersen, Nickel, Zantop, \& Zernial, 2005).

Overall, $53.9 \%$ of injuries were reported as new incident, similar to (Pikora et al., 2011), being the knee and the lumbar spine the two most injured region and affected areas for those that have chronic pain during kitesurfing. This chronic pain is associated to an old injury in consequence of kitesurfing practice, indicated as a poor landing or after a trick. According to this fact we think that all persons involved in the treatment, rehabilitation, and training of kitesurfers must have a special regard on the mechanism and action of the knee as well mobility and stabilization of the lumbar spine. 
Similar to (Cruz et al., 2009; Nickel et al., 2004; Pikora et al., 2011), the majority of the injuries occur in the water and in consequence of a problem when landing or doing a maneuver. In broad-spectrum, $66 \%$ of the participants reported more than one injury. Other interesting result is the fact that $32.1 \%$ of the subjects did not require any medical treatment and $13.2 \%$ used other treatment as a first aid kit or bed rest. If we combine these two indicators, the majority of the injuries $45.3 \%$ did not require a specialized treatment, contrasting with $43.4 \%$ that consulted a physician. It seems that this is related to the fact that the majority of participants perform the freeride style. This kitesurf style is about having fun and learning new techniques something between crossing, a moderately intense activity (Vercruyssen et al., 2009), which lead to less risks than freestyle that involve big air jumps to perform several tricks, where aerobic and anaerobic metabolism contribute to energy delivery (Camps, Vercruyssen, \& Brisswalter, 2011).

Some methodological limitations may have some impact on the results. The fact that it is a web-base, a 12 month's retrospective study and a self-reported questionnaire may introduce bias into the study. However, the answers were confidential and the subjects would not be able to be identified. One the other hand it was expected that kitesurfers were experienced and frequent users of the Internet (Lundgren et al., 2011). The retrospective studies are common in this kind of kitesurfing injury prospection (Lundgren et al., 2011; Pérez-Turpin et al., 2011; Petersen et al., 2005; Pikora et al., 2011; Wegner \& Wegener, 2012). Furthermore, it was not possible to estimate the injury rates, because the majority of the subjects were not able to accurately estimate the number of hours spent kitesurfing, confirming the observation of (Bourgois et al., 2014) . Finally, because of the sample size and distribution, the data can't be generalized for the all Portuguese kitesurfers, but perhaps from those from the North of Portugal.

\section{CONCLUSION}

In conclusion, and independently of the kind of training, kitesurfers that enroll a physical fitness program to improve kitesurfing had less injuries

The lower extremities, especially the knee, were the most frequent locations of injury, occurring typically in the water and in consequence of a problem when landing or doing a maneuver. The assumptions that Kitesurfers with an initiation course, more experience (in years), that perform warm up and use protective equipment have less injuries were not verified. As a result, it is necessary to look at data from a behavioral point of view when perceiving risky behaviors. This association is in consequence of the fact that only $56.3 \%$ use protective equipment, but not every time they practice, and the same with the warm up, that only $14.9 \%$ of the subjects assumed to do it always.

Future research is needed to evaluate the impact of new protective equipment, especially in the lower limbs, and to take in consideration that some high-risk sport participants take deliberately risk behaviors, trying to identify the true injury risk from kitesurfing.

\section{Acknowledgments:}

The authors thank to all the kitesurfers who agreed to participate in the study and contributed to its diffusion in the social networks

\section{Conflicts of Interest:}

Nothing to declare.

\section{Funding:}

Nothing to declare.

\section{REFERENCES}

Ament, W., \& Verkerke, G. J. (2009). Exercise and fatigue. Sports Med, 39(5), 389-422. http://doi.org/10.2165/00007256200939050-00005

Berneira, J. de O., Domingues, M. R., Medeiros, M. A. de, \& Vaghetti, C. A. O. (2011). Incidência e características das lesões em praticantes de kitesurf. Revista Brasileira de Cineantropometria \& Desempenho Humano, 
13(3),

195-201.

http://doi.org/10.1590/s1980-

00372011000300006

Bourgois, J. G., Boone, J., Callewaert, M., Tipton, M. J., \& Tallir, I. B. (2014). Biomechanical and Physiological Demands of Kitesurfing and Epidemiology of Injury Among Kitesurfers. Sports Medicine, 44(1), 55-66. http://doi.org/10.1007/s40279-013-0103-4

Camps, A., Vercruyssen, F., \& Brisswalter, J. (2011). Variation in heart rate and blood lactate concentration in freestyle kytesurfing. Journal of Sports Medicine and Physical Fitness, 51(2), 313-21.

Clarsen, B., \& Bahr, R. (2014). Matching the choice of injury/illness definition to study setting, purpose and design: one size does not fit all! Brithis Journal of Sports Medicine, 48(7), 5102. http://doi.org/10.1136/bjsports-2013093297

Cruz, W. S., Brito, P. M., \& Cruz, N. S. O. (2009). Prevalência das lesões Desportivas MúscloEscléticas dos praticantes de Kitesurf do Estado de Paraíba. Revista Ciência \& Saúde, número especial, 108.

Kupciw, D., \& MacGregor, A. (2012). High-risk sport research. The Sport and Exercise Scientist, (31), 28-28.

Lundgren, L., Brorsson, S., \& Osvalder, A. (2011). Injuries related to kitesurfing. World Academy of Science Engineering and Technology, International Science Index 53, 5(5), 1132-1136.

Machado, M. T., \& Coertjens, M. (2011). Kitesurfing: Mecanismos de Lesão e Marcadores Bioquímicos, (30), 31-39.

Nickel, C., Zernial, O., Musahl, V., Hansen, U., Zantop, T., \& Petersen, W. (2004). A prospective study of kitesurfing injuries. American Journal of Sports Medicine, 32(4), 921-927. http://doi.org/10.1177/0363546503262162

Noakes, T. D. (2000). Physiological models to understand exercise fatigue and the adaptations that predict or enhance athletic performance. Scand J Med Sci Sports, 10(3), 123-45. http://doi.org/10.1034/j.16000838.2000.010003123.x

Pérez-Turpin, J. A., Cortell-Tormo, J. M., C, S.-L., J.J., C.-M., Cejuela-Anta, R., \& Andreu-Cabrera, E. (2012). Lesiones en Windsurfistas de élite masculinos. Revista Internacional de Medicina $Y$ Ciencias de La Actividad Física Y El Deporte, 12(45), 83-92.

Pérez-Turpin, J. A., Cortell-Tormo, J. M., SuárezLlorca, C., Jove-Tossi, M., Andreu-Cabrera, E., \& Carrasco-Embuena, V. (2011). Lesiones en kitesurfistas de élite masculinos. RETOS. Nuevas Tendencias En Educación Física, Deporte Y Recreación, (20), 30-32.

Petersen, W., Nickel, C., Zantop, T., \& Zernial, O. (2005). Kitesurfing injuries. A young sport. Orthopade, 34(5), 419-+. http://doi.org/10.1007/s00132-005-0792-y

Pikora, T. J., Braham, R., Hill, C., \& Mills, C. (2011). Wet and wild: results from a pilot study assessing injuries among recreational water users in Western Australia. International Journal of Injury Control and Safety Promotion, $18(2)$,

$119-26$. http://doi.org/10.1080/17457300.2010.54033 3

Powell, C. (2007). The perception of risk and risk taking behavior: implications for incident prevention strategies. Wilderness \& Environmental Medicine, 18(1), 10-5.

Vercruyssen, F., Blin, N., L'Huillier, D., \& Brisswalter, J. (2009). Assessment of physiological demand in kitesurfing. European Journal of Applied Physiology, 105(1), 103-9. http://doi.org/10.1007/s00421-008-0879-3

Wegner, M., \& Wegener, F. (2012). The relationship between sensation seeking and tendency to suffer injuries among kite surfers. Zeitschrift Für Sportpsychologie, 19(3), 122-130. http://doi.org/10.1026/1612-5010/a000076

Ziegler, M., Lockemann, U., \& Püschel, K. (2009). Fatal accident during kite surfing lesson. Rechtsmedizin, 19(3), 162-164. http://doi.org/10.1007/s00194-008-0582-z 